\title{
TRANSFER PENGETAHUAN TERENCANA DAN TIDAK TERENCANA PADA PROSES REGENERASI PERUSAHAAN KELUARGA DI INDONESIA
}

\author{
Gabriella Hanny Kusuma \\ Universitas Atma Jaya Yogyakarta \\ e-mail: hanny.kusuma@gmail.com; hanny_kusuma@staff.uajy.ac.id
}

\begin{abstract}
This research is to investigate planned and unplanned knowledge transfer in the family business. This research using qualitative study with multiple-casestudy. Sample size amounted to 14 family business consisting of 23 participants. Data obtained with in-depth interviews with semi-structured questions. Data analysis using content analysis method and then processed using the visual map and temporal bracketing. This research uses source triangulation technique and member checking as tools to test validity and reliability. Results show that the factors influencing planned and unplanned knowledge transfer process are: 1) awareness of precursor to transfer knowledge to the successor, 2) their inisiators to do the knowledge transfer process, 3) orientation of predecessors, whether predecessors have a long or short term orientation, 4) expectations of predecessor to the successor, if the predecessor has the expectation that the successor would continue his efforts. Transfer of knowledge that is planned to run systematically, while that's unplanned to run flowing. Initiating knowledge transfer can be initiated by the predecessor and successor. At companies that are planning the transfer of knowledge, initiation is done by predecessor. In companies that do not do the knowledge transfer process, the initiation of the process tends to be done at the force of the need for regeneration process.
\end{abstract}

Keywords: knowledge transfer, family business, qualitative, case study

\begin{abstract}
Abstrak
Penelitian ini bertujuan menggali transfer pengetahuan yang terencana dan tidak terencana pada perusahaan keluarga. Penelitian ini merupakan bersifat kualitatif dengan multiple-casestudy. Ukuran sampel berjumlah 14 perusahaan keluarga yang terdiri dari 23 partisipan. Data digali dengan wawancara mendalam dengan pertanyaan semi terstruktur. Analisa data menggunakan metode content analysis dan kemudian diolah menggunakan metode peta visual dan temporal bracketing. Penelitian ini menggunakan triangulasi sumber dan member checking sebagai validitas dan reliabilitas. Hasil penelitian menunjukkan bahwa elemen yang mempengaruhi proses transfer pengetahuan terencana atau tidak adalah: 1) Kesadaran pendahulu untuk melakukan transfer pengetahuan kepada penerus, 2) Adanya inisiator untuk melakukan proses transfer pengetahuan. 3) Orientasi pendahulu, apakah pendahulu memiliki orientasi jangka panjang ataukah pendek, dan 4) ekspektasi pendahulu kepada penerus, apakah pendahulu memiliki ekspektasi bahwa penerus akan melanjutkan usahanya. Transfer pengetahuan yang direncanakan akan berjalan secara sistematis, sedangkan yang tidak terencana akan berjalan mengalir. Dimulainya transfer pengetahuan bisa diinisiasi oleh pendahulu maupun penerus. Pada perusahaan yang merencanakan proses transfer pengetahuan, inisiasi dilakukan oleh pendahulu. Pada perusahaan yang tidak melakukan proses transfer pengetahuan, inisiasi dimulainya proses tersebut cenderung dilakukan atas desakan kebutuhan melakukan proses regenerasi.
\end{abstract}

Kata kunci: transfer pengetahuan, perusahaan keluarga, kualitatif, case study.

\section{PENDAHULUAN}

Perusahaan keluarga memiliki peranan penting pada perekonomian dan menjadi tulang punggung pertumbuhan ekonomi. Merujuk pada data Badan Pusat Statistik (BPS), mayoritas perusahaan di Indonesia adalah perusahaan keluarga. Pada tahun 2010 perusahaan keluarga di Indonesia berkontribusi sebesar $82,44 \%$ pada 
Pedapatan Domestik Bruto (PDB) Indonesia. Menurut data Indonesian Institute for Corporate and Directorship (IICD, 2010), lebih dari 95 persen bisnis di Indonesia merupakan perusahaan yang dimiliki maupun dikendalikan oleh keluarga, bahkan, banyak perusahaan go public yang sahamnya masih dikuasai oleh keluarga (Djatmiko, 2011). Sebanyak $67 \%$ perusahaan yang melakukan IPO pada rentang tahun 2000-2009 merupakan perusahaan keluarga.

Topik yang menjadi isu utama bagi perusahaan keluarga adalah permasalahan regenerasi serta keberlanjutan perusahaan keluarga setelah terjadi suksesi oleh generasi selanjutnya (Cabrera-Suarez, De Sea-Perez, \& GarciaAlmeida, 2001). Mayoritas perusahaan keluarga hanya mampu bertahan sampai dengan generasi pendiri (Chirico, Knowledge Accumulation in Family Firms: Evidence from Four Case Studies, 2008). Penelitian di Inggris menunjukkan $30 \%$ perusahaan keluarga yang mampu bertahan sampai generasi kedua, dan hanya $13 \%$ perusahaan mencapai generasi ketiga. Tingkat keberhasilan bertahan hidup (Survival rate) perusahaan keluarga di Indonesia tidak terlalu baik. Berdasarkan Boston Consulting Group pada tahun 2012. (Swa, 2013), perusahaan keluarga di Indonesia yang berhasil melakukan transisi dari generasi 1 ke generasi ke-2 hanya sebesar $30 \%$, yang berarti $70 \%$ perusahaan gagal melakukan transisi. Sedangkan keberhasilan transisi perusahaan dari generasi kedua ke generasi ketiga hanya sebesar $7 \%$ dari perusahaan keluarga.

Faktor utama penyebab kegagalan perusahaan keluarga adalah kegagalan pada saat mentransfer perusahaan (i.e. pengetahuan) kepada generasi berikutnya (Kimhi, 1997; Floren, 2002). Proses alih generasi pada perusahaan keluarga adalah proses yang sulit, memakan waktu, dan beresiko. Proses transfer yang tidak mudah dan lama ini menimbulkan ketidakstabilan dan ketidakpastian di dalam perusahaan keluarga (Trevinyo-Rodriguez \& Tapies, 2006).

Pendahulu harus memperhatikan tiga elemen transfer ketika melakukan proses regenerasi. Ketiga elemen tersebut adalah: kekuasaan (power), tanggungjawab manajerial, dan kompetensi (i.e. pengetahuan) (TrevinyoRodriguez \& Tapies, 2006; Varamaki, Pihkala, \& Routama, 2003). Dari ketiga elemen tersebut, transfer pengetahuan menjadi fondasi dari seluruh proses transfer yang terjadi di dalam perusahaan keluarga. Proses tersebut difasilitasi oleh relasi yang kuat antar generasi (Higginson, Preparing the next generation for the family business: relational factors and knowledge transfer in mother - to daughter sucession, 2009).

Pengetahuan pada perusahaan keluarga memiliki bentuk tacit, eksplisit, maupun idiosyncratic (Chirico, 2008; Lee, Lim, \& Lim, 2003; Trevinyo-Rodriguez \& Tapies, 2006). Karakteristik dan risiko tersebut memunculkan dilema dalam pengelolaan pengetahuan pada perusahaan keluarga (Jassimuddin, Klein, \& Connel, 2005). Dilema dan risiko yang muncul dari karakteristik dari masing-masing bentuk pengetahuan berdampak pada pengelolaan pengetahuan pada perusahaan keluarga (Jassimuddin et al., 2005), yang pada kelanjutannya akan berpengaruh pada proses transfer pengetahuan dalam perusahaan keluarga (Chirico, 2008; Trevinyo-Rodriguez \& Tapies, 2006).

Penerus harus menguasai pengetahuan yang dimiliki oleh pendahulu supaya mendapatkan kredibilitas dari pemangku kepentingan perusahaan (Chirico, 2008). Pendahulu dan penerus harus memastikan proses transfer pengetahuan berjalan dengan baik sehingga semua pengetahuan yang dimiliki pendahulu bisa ditransfer seluruhnya kepada penerus (Chirico, 2008; Trevinyo-Rodriguez \& Tapies, 2006; Cabrera-Suarez et al, 2001).

Higginson (2009) meneliti tentang faktor relasi dan transfer pengetahuan antara ibu dan anak perempuan dalam perusahaan keluarga dengan menggunakan metode kualitatif beragam studi kasus (multiple-case studies). Hasil penelitian tersebut menegaskan bahwa transfer pengetahuan dan kapabilitas dari ibu kepada anak perempuannya merupakan bagian yang penting dan esensial dalam perjalanan hidup perusahaan keluarga. Penelitian tersebut menjabarkan elemen-elemen relasi yang mendukung proses transfer pengetahuan antara ibu dan anak perempuannya. Elemen-elemen tersebut mencakup kognisi, afeksi, refleksi, dan struktural. Higginson (2009) menekankan pentingnya sinergi dari keempat elemen tersebut dalam proses transfer pengetahuan antara ibu dan anak perempuannya. Selain keempat elemen tersebut, penelitian yang dilakukan oleh 
Higginson juga menemukan pentingnya membangun jaringan di luar keluarga, dan mengenalkan anak kepada jaringan tersebut sedini mungkin. Pentingnya membangun pemahaman bersama dan berbagi istilah, memelihara keterbukaan atas pengalaman dan ide-ide baru, dan mengelola proses emosional. Proses transfer pengetahuan antara ibu dan anak dipengaruhi oleh kesenjangan generasi (generation gap) dimana kebiasaan, nilai, dan budaya antara generasi ibu dan generasi anak berbeda (Higginson, 2009). Penelitian tersebut juga menangkap adanya fenomena berbeda pada proses transfer pengetahuan antara Bapak dan anak perempuannya. Berdasarkan hal tersebut, untuk penelitian selanjutnya Higginson (2009) mengusulkan untuk mengkaji proses transfer pengetahuan antar generasi yang terjadi pada perusahaan keluarga dengan mempertimbangkan aspek gender dan etnis.

Penelitian ini akan mengkaji proses transfer pengetahuan yang terjadi dalam perusahaan keluarga di Indonesia. Penelitian ini menggunakan sampel perusahaan keluarga dengan latar belakang etnis yang berbeda. Perusahaan keluarga yang menjadi sampel adalah perusahaan keluarga yang dimiliki oleh etnis China dan etnis Jawa.Kedua etnis ini dipilih karena keduanya memiliki beberapa kesamaan sekaligus perbedaaan karakteristik. Kedua etnis tersebut memiliki budaya patriarki dimana laki-laki adalah pemimpin perusahaan. Namun, etnis China cenderung aktif dan berani mengambil resiko (risk taker) demi kemajuan usahanya (Seng, 2007) dansebaliknya, etnis Jawa memiliki tradisi yang mengajarkan untuk sabar, melepaskan diri dari keduniawian, dan menerima nasib dengan rela (Koentjaraningrat, 1984). Hal ini menyebabkan orang Jawa cenderung pasif dan menghindari resiko (risk averse). Karakter etnis yang berbeda tersebut diharapkan akan memperkaya kajian mengenai proses transfer pengetahuan antar generasi yang ada saat ini.

Proses transfer pengetahuan dalam proses alih generasi dianggap sebagai proses yang berlangsung begitu saja (transmission for granted) (Trevinyo-Rodriguez \& Tapies, 2006). Kajian mengenai proses transfer pengetahuan antar generasi di dalam perusahaan keluarga masih minim dilakukan (Chirico, 2008; Varamaki et al., 2003). Dengan demikian, proses transfer pengetahuan antar gene- rasi belum banyak dipelajari secara luas dan mendalam (Chirico, 2008). Studi yang dilakukan oleh The Economist Inteligence Unit (2014) menunjukkan bahwa $78 \%$ perusahaan keluarga di Indonesia memiliki perencanaan dalam hal proses regenerasi (i.e. transfer pengetahuan), yang berarti masih ada $22 \%$ perusahaan keluarga di Indonesia yang belum merencanakan proses regenerasi (i.e. transfer pengetahuan).

Berdasarkan pemaparan diatas, penelitian ini akan mengkaji proses transfer pengetahuan antar generasi pada perusahaan keluarga di Indonesia. Pengkajian terutama fokus pada proses transfer pengetahuan yang terencana dan tidak terencana pada perusahaan keluarga di Indonesia.

\section{KAJIAN PUSTAKA}

\section{Perusahaan Keluarga}

Perusahaan keluarga adalah sebuah usaha yang dimiliki dan dikelola oleh satu atau lebih anggota keluarga (Hollander et al., 1988 dalam Floren, 2002) dan diharapkan akan diwariskan dari satu generasi ke generasi berikutnya (Ward, 1987, dalam Chirico, 2008). Floren (2002) menggolongkan suatu perusahaan sebagai perusahaan keluarga apabila memenuhi dua dari tiga kriteria ini: 1) $50 \%$ dari perusahaan dimiliki oleh satu keluarga, 2) satu keluarga memiliki pengaruh yang signifikan terhadap pengambilan keputusan strategi perusahaan, 3) mayoritas atau paling tidak dua anggota dari manajemen perusahaan berasal dari satu keluarga.

Perusahaan keluarga pada umumnya tidak jauh berbeda dengan perusahaan non keluarga (Cabrera-Suarez et al., 2001; Trevinye Rodriguez \& Tapies, 2006). Perbedaan signifikan antara perusahaan keluarga dan non keluarga adalah keterlibatan ikatan keluarga di dalam perusahaan (Cabrera-Suarez et al., 2001; Chirico, 2008; Floren, 2002). Ikatan keluarga ini disebut dengan familiness yang menjadi karakteristik utama dari perusahaan keluarga (Cabrera-Suarez et al., 2001; Higginson, 2009).

Keluarga terhubung oleh ikatan emosional, berorientasi pada internal, dan memiliki loyalitas yang tinggi, serta menekankan pada pentingnya perhatian pada anggota keluarga. Hal ini membentuk sistem kekeluargaan yang kuat dan terjadi dalam perusahaan keluarga (Floren, 2002). Sistem kekeluargaan ini membuat per- 
usahaan keluarga cenderung membatasi terjadinya perubahan dan menjaga keseimbangan dalam keluarga. Hal inilah yang dapat meminimalisir bahkan meniadakan konflik dalam perusahaan keluarga (Floren, 2002).

Jika sistem kekeluargaan berorientasi kepada keseimbangan dan meminimalisir konflik, maka sistem bisnis perusahaan non keluarga berorientasi pada ekternal dan penyelesaian tugas (Floren, 2002). Sistem bisnis bertujuan memproduksi barang atau jasa untuk mendapatkan keuntungan. Supaya bertahan hidup, sistem bisnis menggunakan perubahan untuk secara efektif menyesuaikan diri terhadap lingkungan. Pada perusahaan keluarga, kedua sistem ini saling berinteraksi dan tumpang tindih, dan juga bergantung satu dengan lainnya (Floren, 2002). Perusahaan harus mampu menyeimbangkan antara sistem kekeluargaan dan sistem bisnis. Keseimbangan antara sistem kekeluargaan dan sistem bisnis ini adalah hal yang penting namun sulit untuk dilakukan (Floren, 2002). Perbedaan antara sistem keluarga dan sistem bisnis bisa dilihat pada Tabel 1.

\section{Karakteristik Perusahaan Keluarga}

Perusahaan keluarga pada umumnya tidak jauh berbeda dengan perusahaan non keluarga (Cabrera Suarez et al., 2001; Trevinyo-Rodriguez \& Tapies, 2006). Ada beberapa karakteristik spesifik yang membedakan perusahaan keluarga dengan perusahaan non keluarga. Karakteristik tersebut mencakup: dedikasi dan komitmen (Cabrera-Suarez et al., 2001), fleksibilitas, stabilitas, orientasi jangka panjang, pengambilan keputusan yang cepat (Floren, 2002), tingkat kepercayaan (Floren, 2002; Trevinyo-Rodriguez \& Tapies, 2006), faktor emosi (Floren, 2002), dan pengetahuan idiosyncratic (Lee et al., 2003). Karakteristik- karakteristik tersebut akan dijabarkan pada bagian selanjutnya.

Dedikasi dan komitmen. Dedikasi dan komitmen yang tinggi diantara orang-orang dalam perusahaan keluarga menjadi salah satu karakteristik perusahaan keluarga (CabreraSuarez et al., 2001). Meskipun, dedikasi dan komitmen juga bisa ditemukan pada perusahaan non keluarga. Faktor yang membedakan dedikasi dan komitmen di perusahaan keluarga dengan perusahaan non keluarga adalah nilainilai keluarga yang berpengaruh pada pembentukan dedikasi dan komitmen tersebut (Floren, 2002). Dengan adanya dedikasi dan komitmen, anggota keluarga merasa memiliki tanggungjawab atas perusahaan, sama dengan karyawan yang bertanggungjawab pada perusahaan non keluarga (Cabrera-Suarez et al., 2001).

Fleksibilitas. Bagi anggota keluarga, perusahaan keluarga lebih dari sekedar pekerjaan namun terkait juga dengan cara hidup. Nama keluarga terhubung dengan reputasi perusahaan (Floren, 2002). Untuk menjaga kinerja dan reputasi perusahaan, anggota keluarga akan lebih fleksibel dalam mengalokasikan waktu dan dana ekstra bagi perusahaan untuk beradaptasi dengan lingkungan (Floren et al., 2005 dalam Warnar, 2012).

Stabilitas. Perusahaan keluarga cenderung stabil dari sisi struktur organisasi dan budaya perusahaan. Perusahaan keluarga memiliki struktur yang stabil karena masa kepemimpinan di dalam perusahaan keluarga cenderung lebih lama daripada perusahaan non keluarga (Floren, 1998). Budaya perusahaan dipengaruhi oleh norma, nilai, dan kode etik yang ada pada keluarga, sehingga apabila generasi berikutnya mengambil alih kepemimpinan, maka budaya perusahaan cenderung tidak berubah dan stabil (Floren, 2002).

Tabel 1: Perbedaan antara sistem keluarga dan sistem bisnis

\begin{tabular}{lll}
\hline \multicolumn{1}{c}{ Faktor } & \multicolumn{1}{c}{ Sistem Kekeluargaan } & \multicolumn{1}{c}{ Sistem Bisnis } \\
\hline Relasi & Terhubung karena kelahiran & Bergabung atas pilihan pribadi \\
Durasi & Seumur hidup & Untuk sementara \\
Pengambilan keputusan & Berdasarkan Emosi & Berdasarkan rasio \\
Perilaku & Unconscious Behavior & Conscious Behavior \\
Penghargaan & Penghargaan $($ reward $)$ & Penghargaan $($ reward $)$ \\
& berdasarkan kesetaraan & berdasarkan pencapaian hasil \\
Orientasi & Internal & Eksternal \\
Sifat & Konservatif & Dinamis \\
\hline
\end{tabular}

Sumber: Floren (2002) 
Orientasi Jangka Panjang.Perusahaan keluarga lebih fokus pada pencapaian jangka panjang dan keberlangsungan perusahaan. Perusahaan non keluarga sering harus berurusan dengan pihak eksternal yang berfokus pada orientasi jangka pendek, seperti investor dan pemegang saham (Floren et al., 2005, dalam Warnar 2012).Pada perusahaan non keluarga sering terjadi konflik antara manajemen dan pemilik karena masalah perbedaan orientasi. Pada perusahaan keluarga relasi kekeluargaan antara pemilik dan manajer mengurangi biaya terkait masalah keagenan dan memungkinkan perusahaan keluarga memiliki orientasi jangka panjang (Bennedsen, Nielsen, Perez-Gonzales, \& Wolfenzon, 2007).

Pengambilan keputusan yang cepat. Budaya yang ada di perusahaan selain memberi rasa memiliki bagi para karyawan juga memberikan akses yang mudah ke manajemen. Di perusahaan keluarga keputusan terbatas pada satu atau dua orang anggota keluarga, sehingga birokrasi yang ada di perusahaan keluarga sangat minim. Konsekuensinya, pengambilan keputusan pada perusahaan keluarga dapat dilakukan dengan lebih cepat (Floren et al., 2005, dalam Warnar, 2012).

Tingkat kepercayaan. Secara internal, adanya relasi kekeluargaan membuat tingkat kepercayaan antar personal dalam perusahaan keluarga lebih tinggi daripada pada perusahaan non keluarga (Cabrera-Suarez et al., 2001; Trevinyo-Rodriguez \& Tapies 2006). Secara eksternal, stabilitas dan komitmen dari karyawan merupakan dasar dari perusahaan keluarga menjadi mitra bisnis yang dipercaya. Bagi pemangku kepentingan, komitmen dari karyawan dapat mengurangi resiko usaha karena tingkat pengunduran diri karyawan (turnover) yang rendah. Selain itu, perusahaan keluarga memiliki orientasi jangka panjang daripada keuntungan jangka pendek (Dreux, 1990, dalam Warnar, 2012).

Faktor emosi. Sistem kekeluargaan dipengaruhi oleh faktor emosi, sedangkan sistem bisnis dipengaruhi oleh faktor rasional. Dalam konteks perusahaan keluarga kedua sistem tersebut berlaku. Tidak mengherankan jika pengambilan keputusan penting seperti pemilihan pemimpin perusahaan sering dipengaruhi oleh pertimbangan-pertimbangan emosional. Selain itu, pada perusahaan keluarga sering terjadi percampuran antara permasalahan keluarga dan permasalahan perusahaan. Konflik perebutan hak waris antar saudara merupakan permasalahan yang sering muncul pada perusahaan keluarga (Floren, 2002).

Pengetahuan idiosyncratic. Pengetahuan yang dimiliki oleh perusahaan merupakan elemen penting dalam memelihara dan meningkatkan kinerja perusahaan (Chirico, Knowledge Accumulation in Family Firms: Evidence from Four Case Studies, 2008). Pengetahuan yang ada pada perusahaan keluarga sering berupa pengetahuan idiosyncratic yang bersifat personal. Pengetahuan ini merupakan pengetahuan yang aman dari resiko imitasi karena sifatnya yang personal sehingga hanya mungkin diakses oleh anggota keluarga atau orang yang dipercaya (Lee et al, 2003).

\section{Transfer Pengetahuan dalam Proses Suksesi Perusahaan Keluarga}

Proses transfer pengetahuan antar generasi pada perusahaan keluarga tidak lepas dari proses alih generasi. Bahkan, proses transfer pengetahuan menjadi fondasi dari proses alih generasi pada perusahaan keluarga (Higginson, 2009).

Secara umum, perusahaan keluarga melakukan transfer kepemimpinan (i.e. pengetahuan) kepada satu atau beberapa anggota keluarga (Beek, 2004, dalam Warnar, 2012). Keputusan untuk mengalihkan perusahaan kepada anggota keluarga lebih didorong oleh keputusan emosional dibandingkan keputusan rasional (Floren et al., 2005, dalam Warnar 2012). Keputusan emosional ini juga didasari karena adanya nepotisme yang umum terjadi di perusahaan keluarga (Bertrand \& Schoar, 2006), Pemilik perusahaan akan cenderung memilih anak atau kerabat dekatnya yang memiliki kapabilitas terbatas untuk menjadi penerus, dibandingkan memilih manajer yang berasal dari luar keluarga meskipun kapabilitasnya lebih baik (Bertrand \& Schoar, 2006).

Selain karena faktor emosional dan nepotisme, pendahulu memilih penerus yang berasal dari keluarga juga disebabkan oleh karakter pengetahuan pada perusahaan keluarga yang berupa pengetahuan idiosyncratic. Pendahulu berupaya menjaga kerahasiaan dengan mewariskan pengetahuan idiosyncratic tersebut kepada anggota keluarga (Lee et al., 2003). 
Relasi berperan penting dalam proses transfer pengetahuan pada perusahaan keluarga. Lebih spesifik, kualitas relasi antara pendahulu dan penerus juga mempengaruhi transfer pengetahuan pada perusahaan keluarga (Kimhi, 1997). Relasi kekeluargaan yang kuat sehingga memudahkan terjadinya transfer pengetahuan (Trevinyo-Rodriguez \& Tapies, 2006). Seperti halnya di perusahaan non keluarga, perusahaan keluarga juga tidak secara otomatis terbebas dari konflik. Karenanya ketidakpastian kualitas relasi juga mungkin terjadi pada perusahaan keluarga (Kimhi, 1997).

Organisasi yang mandul dan relasi yang sulit akan menghambat proses transfer pengetahuan dari pendahulu kepada penerus (Szulanski, 1996). Proses transfer pengetahuan melekat dengan karakteristik perusahaan. Perusahaan keluarga yang disebut dengan subur adalah perusahaan keluarga yang mendukung proses transfer pengetahuan, dan sebaliknya disebut dengan mandul (Szulanski, 1996).

Jumlah penerus juga berpengaruh pada proses transfer pengetahuan. Pendahulu harus menentukan siapa yang akan menjadi penerus, dan bagaimana posisi anak yang lain di dalam perusahaan (Chrisman, Chua, Pearson, \& Barnett, 2012; Kimhi, 1995). Kondisi ini berpotensi menimbulkan konflik dan perpecahan dalam keluarga.

Higginson (2009) mengusulkan penelitian proses transfer pengetahuan dilakukan pada perusahaan dengan etnis yang berbeda. Etnis mempengaruhi nilai, budaya, perilaku, dan pengelolaan perusahaan (Higginson, 2009). Sebagai contoh, perusahaan keluarga yang diteliti dalam penelitian ini adalah perusahaan keluarga yang dimiliki oleh etnis China dan etnis Jawa. Kedua etnis ini memiliki karakteristik yang berbeda. Pengusaha dari etnis China cenderung aktif dan berani mengambil resiko (risk taker) demi kemajuan usahanya (Seng, 2007). Sebaliknya, orang Jawa memiliki tradisi yang mengajarkan untuk sabar, melepaskan diri dari keduniawian, dan menerima nasib dengan rela (Koentjaraningrat, 1984). Hal ini menyebabkan orang Jawa cenderung pasif dan menghindari resiko (risk averse).

Pada perusahaan keluarga, pendahulu mengajarkan segala sesuatu yang ia ketahui kepada penerus (Trevinyo-Rodriguez \& Tapies, 2006). Hal tersebut terjadi karena tingkat kepercayaan yang tinggi dan relasi yang kuat antara pendahulu dan penerus (Cabrera-Suarez et al., 2001; Higginson, 2009; TrevinyoRodriguez \& Tapies, 2006). Pendahulu secara total mentransfer pengetahuannya kepada penerus dengan harapan penerus mampu menjaga keberlangsungan perusahaan (Trevinyo-Rodriguez \& Tapies, 2006). Pada perusahaan keluarga, pendahulu dan penerus memiliki keselarasan kepentingan terhadap perusahaan (Trevinyo-Rodriguez \& Tapies, 2006). Adanya keselarasan kepentingan ini membuat permasalahan terkait sifat oportunis dan informasi yang asimetris (asymmetris information) pada perusahaan keluarga relatif jarang terjadi (DeMassis, Federico, Pizzumo, \& Cassia, 2011).

Faktor kunci keberhasilan perusahaan keluarga adalah saling menghormati dan memahami antara generasi pendahulu dan anggota-anggota keluarga generasi penerus (Classen, Carree, Gils, \& Peters, 2014). Anggota keluarga yang tidak aktif dalam perusahaan dapat memberi pengaruh pada proses transfer pengetahuan pada perusahaan keluarga (Tatoglu, Kula, \& Glaister, 2008). Sebagai contoh, secara khusus seorang ibu dari penerus dapat bertindak sebagai penyangga tidak terlihat (silent buffer) antara dua generasi (Janjuha et al., 2002 dalam Tatoglu et al., 2008).

Proses alih generasi dikatakan berhasil apabila penerus telah mendapatkan legitimasi dan diterima secara luas oleh para pemangku kepentingan perusahaan (Tatoglu et al., 2008). Otoritas dan pendelegasian kepada penerus adalah hal yang penting dalam proses ini. Kurangnya delegasi bukan hanya mengganggu proses belajar dari penerus, namun juga mengurangi kredibilitas penerus dimata karyawan dan pemangku kepentingan kunci perusahaan (Fox et al., 1996 dalam Tatoglu et al., 2008).

Transfer pengetahuan melibatkan dua pihak yaitu pemberi dan penerima pengetahuan. Dalam konteks perusahaan keluarga pemberi pengetahuan adalah pendahulu, dan penerima pengetahuan adalah penerus.Teori pemangku kepentingan (stakeholder theory) dapat menjadi lensa yang digunakan dalam penelitian untuk mengkaji siapa saja yang menguasai pengetahuan, dan kepada siapa pengetahuan tersebut ditransfer. 
Tabel 2. Identifikasi pemangku kepentingan

\begin{tabular}{|c|c|c|}
\hline Atribut & Definisi & Dasar \\
\hline Kekuasaan & $\begin{array}{l}\text { Relasi antar aktor dimana satu aktor bisa meminta } \\
\text { aktor yang lain untuk melakukan sesuatu tanpa bisa } \\
\text { dibantah }\end{array}$ & $\begin{array}{ll}\text { - } & \text { Paksaan: Kekuatan/ancaman } \\
\text { - } & \text { Kemanfaatan: insentif materi } \\
\text { - } & \text { Normatif: pengaruh simbolis }\end{array}$ \\
\hline Legitimasi & $\begin{array}{l}\text { Persepsi umum atau asumsi tentang tindakan } \\
\text { seseorang adalah pantas, diharapkan, dan tepat } \\
\text { menurut sistem, norma, nilai, kepercayaan }\end{array}$ & $\begin{array}{ll}\text { - } & \text { Individual } \\
\text { - } & \text { Organizational } \\
\text { - } & \text { Sosial }\end{array}$ \\
\hline Urgensi & $\begin{array}{l}\text { Tingkatan dimana pemangku kepentingan memiliki } \\
\text { klaim untuk diperhatikan }\end{array}$ & $\begin{array}{l}\text { - Sensitifitas waktu: derajad dimana penun- } \\
\text { daan atas klaim atau relasi tidak bisa di- } \\
\text { terima oleh pemangku kepentingan } \\
\text { - Bersifat kritis/mendesak: Pentingnya klaim } \\
\text { atau relasi dari pemangku kepentingan }\end{array}$ \\
\hline
\end{tabular}

\section{Teori Pemangku Kepentingan (Stakeholder Theory)}

Pemangku kepentingan adalah individu atau kelompok yang bisa berpengaruh pada pencapaian tujuan organisasi, atau pihak yang terkena dampak dari pencapaian tujuan organisasi. Pemangku kepentingan memiliki beberapa atribut, yaitu: kekuasaan (power), legitimasi, dan urgensi. Penjabaran atributatribut pemangku kepentingan bisa dilihat pada Tabel 2.

Teori pemangku kepentingan terkait dengan siapa yang memegang kekuasaan, legitimasi, dan mempunyai kepentingan (urgency) di dalam perusahaan keluarga. Dalam konteks transfer pengetahuan, hal tersebut terkait siapa yang memegang kekuasaan dan legitimasi untuk melakukan transfer pengetahuan, menguasai pengetahuan, dan memiliki kepentingan dalam proses transfer pengetahuan.

\section{METODE PENELITIAN}

Penelitian ini menggunakan pendekatan kualitatif dengan beragam studi kasus (multiple-case studies). Pendekatan kualitatif digunakan karena penelitian ini membutuhkan eksplorasi dan pemahaman yang detail akan permasalahan yang diangkat (Creswell, 2010). Penelitian ini membutuhkan partisipan untuk menceritakan pengalamannya dan pemahamannya berkaitan dengan konteks penelitian.Partisipan juga harus menjelaskan kondisi (setting) dimana partisipan berkaitan dengan permasalahan penelitian
(Creswell, 2010). Sejalan dengan penjelasan tersebut, McCollom (1990) dalam Chirico (2008) berpendapat bahwa penelitian kualitatif lebih sesuai untuk mempelajari perusahaan keluarga.

Penggunaan metode studi kasus memungkinkan peneliti untuk memahami fenomena yang terjadi pada kehidupan nyata secara mendalam tanpa mengabaikan kondisi kontekstual yang penting (Yin, 2009). Selain itu, metode ini memungkinkan peneliti memperoleh karakteristik yang menyeluruh dan bernilai dari proses transfer pengetahuan antar generasi pada perusahaan keluarga (Yin, 2009).

Perusahaan-perusahaan dipilih berdasarkan pada teori (theoretical sampling). Setiap perusahaan dipilih berdasarkan kapasitas mereka untuk menjawab pertanyaan penelitian dan kontribusi mereka pada pengembangan teori (Higginson, 2009). Partisipan penelitian ini berasal dari 14 perusahaan dengan 23 orang partisipan yang terdiri dari 16 orang penerus dan 7 orang pendahulu. Data perusahaan yang menjadi partisipan dalam penelitian ini bisa dilihat pada Tabel 4.

Higginson (2008) mengemukakan adanya perbedaan dinamika proses transfer pada perusahaan keluarga yang memiliki karakteristik berbeda. Karakteristik yang dimaksud dalam penelitian ini adalah usia pendahulu dan penerus, gender, jumlah penerus (number of successor) dan etnis (lihat Tabel 3).

Tabel 3: Skema pemilihan sampel perusahaan keluarga

\begin{tabular}{lll}
\hline \multicolumn{1}{c}{ Karakteristik } & & Kategori \\
\hline Usia penerus & Lebih Muda & Lebih Tua \\
Gender antar pendahulu dan penerus & Sama & Berbeda \\
Jumlah calon penerus & Tunggal & Lebih dari satu \\
Etnis & China & Jawa \\
\hline
\end{tabular}


Tabel 4. Profil Partisipan Penelitian

\begin{tabular}{|c|c|c|c|c|c|c|c|c|}
\hline \multirow{2}{*}{ No } & \multirow{2}{*}{$\begin{array}{c}\text { Nama } \\
\text { Perusahaan }\end{array}$} & \multirow{2}{*}{$\begin{array}{l}\text { Tahun } \\
\text { Berdiri }\end{array}$} & \multirow{2}{*}{ Bidang usaha } & \multirow{2}{*}{ Etnis } & \multirow{2}{*}{$\begin{array}{c}\text { Jumlah Calon } \\
\text { Penerus }\end{array}$} & \multicolumn{2}{|c|}{ Gender } & \multirow{2}{*}{ Generasi } \\
\hline & & & & & & Pendahulu & Penerus & \\
\hline 1 & $\mathrm{ABR}$ & 1984 & $\begin{array}{c}\text { Produk } \\
\text { Makanan }\end{array}$ & Jawa & $\begin{array}{l}9 \text { orang }(1 \mathrm{~L} ; 8 \mathrm{P}) \\
3 \text { orang }(2 \mathrm{~L} ; 1 \mathrm{P})\end{array}$ & Perempuan & Laki-laki & $\mathrm{Ke}-3$ \\
\hline 2 & BPP & 2004 & $\begin{array}{c}\text { Produk } \\
\text { Makanan }\end{array}$ & Jawa & 3 orang $(1 \mathrm{P} ; 2 \mathrm{~L})$ & Perempuan & Perempuan & $\mathrm{Ke}-2$ \\
\hline 3 & TGC & 1985 & Jasa Catering & Jawa & 3 orang $(2 \mathrm{~L} ; 1 \mathrm{P})$ & Perempuan & Perempuan & $\mathrm{Ke}-2$ \\
\hline 4 & PAR & 1980 & Produk Batik & Jawa & $\begin{array}{c}6 \text { orang }(5 \mathrm{P} ; 1 \mathrm{~L}) \\
3 \text { orang }(3 \mathrm{P})\end{array}$ & Perempuan & Perempuan & $\mathrm{Ke}-3$ \\
\hline 5 & NM & 1990 & Produk Batik & Jawa & 3 orang $(3 \mathrm{P})$ & Perempuan & Perempuan & $\mathrm{Ke}-3$ \\
\hline 6 & CVA & 2000 & $\begin{array}{c}\text { Jasa } \\
\text { Konstruksi }\end{array}$ & Jawa & 3 orang $(1 \mathrm{~L} ; 2 \mathrm{P})$ & Laki-laki & Laki-laki & $\mathrm{Ke}-2$ \\
\hline 7 & SDB & 1993 & Sanggar seni & Jawa & 3 orang $(2 \mathrm{P} ; 1 \mathrm{~L})$ & Laki-laki & Perempuan & $\mathrm{Ke}-2$ \\
\hline 8 & KBI & 1978 & Jasa Penjahit & Jawa & 2 orang $(1 \mathrm{~L} ; 1 \mathrm{P})$ & Laki-laki & Laki-laki & $\mathrm{Ke}-2$ \\
\hline 9 & AMN & 1990 & $\begin{array}{l}\text { Jasa rental- } \\
\text { multi usaha }\end{array}$ & China & 2 orang $(1 \mathrm{~L} ; 1 \mathrm{P})$ & Laki-laki & Laki-laki & $\mathrm{Ke}-2$ \\
\hline 10 & LSS & 1974 & Percetakan & China & $\begin{array}{l}2 \text { orang }(1 \mathrm{~L} ; 1 \mathrm{P}) \\
8 \text { orang }(3 \mathrm{~L} ; 5 \mathrm{P})\end{array}$ & Perempuan & Laki-laki & $\mathrm{Ke}-3$ \\
\hline 11 & $\mathrm{CFC}$ & 1990 & Jasa Fotocopy & China & 2 orang $(1 \mathrm{P} ; 1 \mathrm{~L})$ & Laki-laki & Laki-laki & $\mathrm{Ke}-2$ \\
\hline 12 & KFS & 1981 & Jasa Fotografi & China & 2 orang $(2 L)$ & Perempuan & Laki-laki & $\mathrm{Ke}-2$ \\
\hline 13 & $\mathrm{ADM}$ & 1985 & $\begin{array}{l}\text { Toko alat } \\
\text { musik }\end{array}$ & China & 2 orang $(2 L)$ & Laki-laki & Laki-laki & $\mathrm{Ke}-2$ \\
\hline 14 & TBD & 1965 & $\begin{array}{c}\text { Toko } \\
\text { Sembako }\end{array}$ & China & 2 orang $(2 \mathrm{P})$ & Perempuan & Perempuan & $\mathrm{Ke}-2$ \\
\hline
\end{tabular}

Sumber: Data penelitian yang diolah

Pengumpulan data dilakukan dengan wawancara secara mendalam kepada pemilik perusahaan keluarga. Wawancara dilakukan kepada pendahulu dan/atau penerus perusahaan. Untuk meningkatkan validitas, data juga didukung oleh dokumen perusahaan, arsip tercatat, observasi langsung, observasi partisipan, dan artefak fisik (Yin, 2009). Pengumpulan data dihentikan apabila data yang diperoleh sudah jenuh (saturated). Kejenuhan dalam pengumpulan data adalah ketika tidak ada informasi baru yang diperoleh. Indikator dari kejenuhan data adalah ketika terjadi replikasi atau pengulangan informasi yang diperoleh dari informan yang berbeda (Creswell, 2010).

Untuk memastikan validitas dan kredibilitas, penelitian ini menggunakan beberapa cara yaitu validasi responden (member checking) dan triangulasi (Yin, 2009; Creswell, 2010; Wahyuni, 2012). Triangulasi yang digunakan dalam penelitian ini adalah triangulasi sumber.

Data diolah menggunakan content analysis, peta visual dan temporal bracketing (Langley, 1999). Strategi peta visual memungkinkan menampilkan data dalam jumlah besar, dan secara mudah digunakan untuk menampilkan gejala, proses pararel, dan berlalunya waktu. Strategi temporal bracketing mentransformasi data yang tidak berbentuk menjadi beberapa bagian yang berurutan namun saling terhubung.

\section{HASIL ANALISIS}

Hasil wawancara dengan partisipan menunjukkan adanya proses transfer pengetahuan yang terencana dan tidak terencana. Pendahulu dari perusahaan KFS mengatakan "Banyak kejadian dimana seorang anak tidak mau meneruskan usaha orang tuanya.Sampai akhirnya orang tua sudah surut dan jatuh, anaknya baru sadar dan baru mau mulai meneruskan.Kalau seperti itu mau mengangkat (kondisi perusahaan) lagi sudah berat, jadi saya sejak awal sudah rencana melibatkan dia (penerus) walaupun pada mulanya dia ribut kalau disuruh membantu." Sbaliknya, pendahulu dari perusahaan NM mengatakan "Saya terlalu sibuk (dengan rutinitas perusahaan), terlalu repot waktunya, sulit sekali untuk memikirkan itu (merencanakan transfer pengetahuan kepada penerus)." Berdasarkan pernyataan tersebut diketahui bahwa Mekanisme perencanaan transfer pengetahuan tergantung dari kesadaran pendahulu untuk melakukan transfer pengetahuan. Pendahulu yang sadar akan pentingnya transfer pengetahuan akan menyusun perencanaan transfer pengetahuan. Sebaliknya pendahulu yang sibuk dengan rutinitas perusahaan dan tidak memikir- 
kan pentingnya transfer pengetahuan, maka pendahulu tersebut tidak menyusun rencana transfer pengetahuan kepada penerus.

Selain kesadaran akan pentingnya transfer pengetahuan, latar belakang seorang pendahulu merencanakan atau tidak proses transfer pengetahuan juga dipengaruhi oleh ekspektasi orang tua kepada anak. Pendahulu yang memiliki ekspektasi bahwa anaknya menjadi pengusaha (penerus perusahaan) akan merencanakan transfer pengetahuan. Hal ini ditegaskan oleh pendahulu dari perusahaan BPP yang mengatakan "Dari awal saya menghendaki dia (penerus) berwiraswasta. Saya lebih suka kalau anak saya (penerus) berwiraswasta karena untuk seorang perempuan waktu untuk keluarga menjadi lebih mudah diatur, dan juga dengan berwiraswasta bisa berbagi lebih banyak kepada orang lain."Sebaliknya, pendahulu yang berekspektasi anaknya memiliki karier di perusahaan besar atau memiliki jabatan di pemerintahan maka dia tidak merencanakan adanya transfer pengetahuan.Pendahulu dari KBI menegaskan hal tersebut dengan menuturkan "Saya pada awalnya memang tidak merencanakan anak saya (penerus) melanjutkan usaha ini.Saya ingin anak saya lebih mulia hidupnya daripada saya. "Pendahulu yang tidak memiliki ekspektasi tertentu kepada anaknya juga cenderung tidak menyusun rencana untuk mentransfer pengetahuan. Hal ini diutarakan oleh pendahulu dari perusahaan NM yang mengatakan "Saya tidak pernah mengarahkan anak saya untuk menjadi apa." Penerus dari perusahaan NM mengkonfirmasi hal tersebut dengan mengatakan "Ibu (pendahulu) tidak pernah secara eksplisit saya harus menjadi apa. Jadi saya di bebaskan mau jadi apa."

Pendahulu yang merencanakan transfer pengetahuan secara matang memiliki skema yang sistematis dan memiliki rentang waktu (time line) yang jelas. Pendahulu merencanakan kapan proses transfer tersebut dimulai dan tahapan-tahapan yang harus dilalui oleh penerus. Hal ini diperkuat oleh pernyataan penerus dari perusahaan ADM yang mengatakan "Saya terlibat sejak SD. Orang tua (pendahulu) sudah buat jalurnya (jalur transfer pengetahuan). Adik (penerus ke-2) mengalami jalur yang sama tetapi proporsional sesuai perkembangan usaha. Saya (penerus) seumur dia lewatnya juga jalur yang sama." Sebaliknya, Pendahulu yang tidak merencanakan proses transfer pengetahuan tidak memiliki skema yang sistematis dan kurun waktu yang jelas kapan akan melakukan transfer pengetahuan. Penerus dari perusahaan ABR menjelaskan hal tersebut dengan mengatakan "Ibuku (pendahulu) masih sangat tradisional sehingga tidak memiliki pemikiran untuk melakukan transfer pengetahuan. Ibu tidak punya skema ini harus bagaimana dilakukan, bagaimana supaya maju."

Pada perusahaan dimana pendahulu merencanakan proses transfer pengetahuan, inisiatif dimulainya proses transfer pengetahuan muncul dari pendahulu. Hal ini diperkuat oleh pernyataan penerus dari perusahaan AMN yang mengatakan "Sewaktu saya semester delapan (8), Papa (pendahulu) menyuruh saya (penerus) membantu di perusahaan." Penerus dari TGC juga memperkuat adanya inisiatif untuk memulai transfer pengetahuan dari pendahulu dengan mengatakan "Sewaktu saya kuliah, ibu sudah bilang bahwa perusahaan ini saya yang meneruskan, semenjak itu saya terlibat penuh membantu ibu (pendahulu)."

Pada perusahaan yang tidak memiliki perencanaan dalam mentransfer pengetahuan, proses transfer pengetahuan akhirnya dilakukan pendahulu karena adanya desakan dari penerus yang berminat untuk melanjutkan perusahaan. Penerus meminta pendahulu untuk mentransfer pengetahuan kepadanya. Inisiatif transfer pengetahuan yang muncul dari penerus seperti yang terjadi pada perusahaan TBD dan ABR. Penerus dari perusahaan TBD mengatakan "Saya yang maju, minta sama mama (pendahulu) untuk mengajari. Mama (pendahulu) tipenya kalau tidak diminta tidak akan diberi, biasa mengerjakan semuanya sendiri. Kalau menunggu mama (punya inisiatif) tidak akan sampai ke saya."Penerus dari perusahaan ABR menuturkan "Kakak saya (penerus 1) yang merencanakan perusahaan ini dilanjutkan.Dia (penerus 1) yang mensetting peran adik-adiknya dalam perusahaan dan meminta ibu untuk mengajari (penerus)."

\section{PEMBAHASAN}

Secara umum, pendahulu dalam perusahaan keluarga memiliki mimpi bahwa anak-anak mereka melanjutkan kepemimpinan perusahaan 
(Trevinyo-Rodriguez \& Tapies, 2006). Hal ini sejalan dengan hasil penelitian dimana pendahulu merencanakan transfer pengetahuan bagi penerus. Pada perusahaan yang merencanakan proses transfer pengetahuan, pendahulu memiliki ekspektasi anak-anaknya akan melanjutkan kepemimpinan perusahaan. Namun, penelitian ini juga mengidentifikasi hal berbeda. Hasil penelitian menunjukkan bahwa tidak semua partisipan memiliki ekspektasi anak-anaknya meneruskan usaha mereka. Ada pendahulu yang mengharapkan anak-anaknya memiliki karier yang lebih baik di perusahaan lain yang lebih besar, dan ada juga pendahulu yang tidak memiliki ekspektasi apapun terhadap penerus. Pendahulu yang seperti itu cenderung tidak merencanakan proses transfer pengetahuan kepada anak-anaknya. Pendahulu yang sibuk dengan rutinitas operasional perusahaan seharihari juga cenderung abai terhadap perencanaan proses transfer pengetahuan bagi penerusnya.

Pendahulu yang merencanakan transfer pengetahuan secara matang memiliki skema yang sistematis dan memiliki rentang waktu (time line) yang jelas. Pendahulu merencanakan kapan proses transfer tersebut dimulai dan tahapan-tahapan yang harus dilalui oleh penerus. Sebaliknya, Pendahulu yang tidak merencanakan proses transfer pengetahuan tidak memiliki skema yang sistematis dan kurun waktu yang jelas kapan akan melakukan transfer pengetahuan.
Pada perusahaan dimana pendahulu merencanakan proses transfer pengetahuan, inisiatif dimulainya proses transfer pengetahuan muncul dari pendahulu. Pada perusahaan yang tidak memiliki perencanaan dalam mentransfer pengetahuan, proses transfer pengetahuan akhirnya dilakukan pendahulu karena adanya desakan kebutuhan atau adanya desakan dari penerus untuk melakukan transfer pengetahuan. Secara ringkas, mekanisme transfer pengetahuan yang terencana maupun tidak terencana dirangkum dalam Tabel 5.

\section{PENUTUP}

Penelitian ini dilakukan dengan tujuan untuk menjawab permasalahan tentang bagaimana proses transfer pengetahuan antar generasi terencana dan tidak terencana, yang terjadi dalam perusahaan keluarga.

Hasil penelitian menunjukkan adanya transfer pengetahuan yang terencana dan tidak terencana. Elemen yang mempengaruhi proses transfer pengetahuan terencana atau tidak adalah: 1) Kesadaran pendahulu untuk melakukan transfer pengetahuan kepada penerus, 2) Adanya inisiator untuk melakukan proses transfer pengetahuan. 3) Orientasi pendahulu, apakah pendahulu memiliki orientasi jangka panjang ataukah pendek, dan 4) ekspektasi pendahulu kepada penerus, apakah pendahulu memiliki ekspektasi bahwa penerus akan melanjutkan usahanya.

Tabel 5. Transfer pengetahuan terencana dan tidak terencana

\begin{tabular}{|c|c|c|}
\hline & Terencana & Tidak Terencana \\
\hline Pendahulu & $\begin{array}{l}\text { Menyadari pentingnya perencanaan } \\
\text { untuk melakukan alih generasi dan } \\
\text { transfer pengetahuan kepada penerus. }\end{array}$ & $\begin{array}{l}\text { Sibuk dengan rutinitas operasional perusahaan } \\
\text { sehari-hari sehingga abai terhadap proses } \\
\text { perencanaan transfer pengetahuan. }\end{array}$ \\
\hline Inisiator & Pendahulu & Penerus atau pendahulu \\
\hline \multirow[t]{2}{*}{ Proses } & Sistematis & Tidak sistematis, mengalir \\
\hline & $\begin{array}{l}\text { Proses transfer pengetahuan dimulai } \\
\text { berdasarkan rencana pendahulu. }\end{array}$ & $\begin{array}{l}\text { Proses transfer pengetahuan dimulai atas } \\
\text { desakan kebutuhan atau desakan dari penerus. }\end{array}$ \\
\hline $\begin{array}{l}\text { Keterlibatan } \\
\text { penerus }\end{array}$ & $\begin{array}{l}\text { Penerus terlibat atas permintaan } \\
\text { pendahulu }\end{array}$ & $\begin{array}{l}\text { Penerus terlibat atas permintaan pendahulu } \\
\text { karena desakan kebutuhan, atau atas keinginan } \\
\text { penerus. }\end{array}$ \\
\hline Orientasi & Jangka panjang. Berorientasi pada & Jangka pendek, sibuk dengan rutinitas \\
\hline Pendahulu & keberlangsungan perusahaan. & operasional perusahaan. \\
\hline Ekspektasi & Pendahulu menginginkan perusahaan & Pendahulu tidak memliki ekspektasi apapun \\
\hline \multirow[t]{2}{*}{ Pendahulu } & diteruskan oleh generasi berikutnya. & pada penerus. \\
\hline & & $\begin{array}{l}\text { Pendahulu memiliki ekspektasi bahwa penerus } \\
\text { memiliki kehidupan lebih baik dengan berkarier } \\
\text { di luar perusahaan milik keluarga. }\end{array}$ \\
\hline
\end{tabular}


Dalam proses pelaksanaan transfer pengetahuan, perbedaan yang muncul adalah sistematika transfer pengetahuan. Pada perusahaan yang terencana, proses transfer pengetahuan berjalan sistematis. Sedangkan pada perusahaan yang tidak terencana, proses transfer pengetahuan berjalan secara mengalir. Di mulainya proses transfer pengetahuan juga berbeda. Pada perusahaan yang terencana, proses transfer pengetahuan dimulai sesuai dengan perencanaan yang dibuat oleh pendahulu. Perusahaan yang tidak merencanakan proses transfer pengetahuan memulai proses tersebut ketika munculnya desakan kebutuhan untuk melakukan regenerasi. Desakan dari penerus kepada pendahulu untuk mentransfer pengetahuannya juga merupakan faktor yang memicu dimulainya transfer pengetahuan pada perusahaan yang tidak merencanakan proses transfer pengetahuan tersebut.

Untuk penelitian selanjutnya ada baiknya untuk menggali proses transfer pengetahuan yang terjadi pada perusahaan yang tidak merencanakan proses transfer pengetahuan. Penelitian bisa juga menggali lebih dalam lagi elemen-elemen yang mendorong suatu perusahaan merencanakan atau tidak merencanakan proses transfer pengetahuan.

\section{DAFTAR PUSTAKA}

Bennedsen, M., Nielsen, K., Perez-Gonzales, F., \& Wolfenzon, D. Inside the family firm: the role of families in succession decisions and performance. Quarterly Journal of Economics. 122(2). 647691.

Bertrand, M. and Schoar, A., 2006.The role of family in family firms. Journal of Economics Perspectives, Volume 20, pp. 73-96.

Cabrera-Suarez, K., De Sea-Perez, P. and Garcia-Almeida, D., 2001. The succession process from a resource-and knowledge based view of the family firm. Family Bussiness Review, pp. 1437.

Chirico, F., 2008. Knowledge Accumulation in Family Firms: Evidence from four case studies. International Small Business Journal No.26, pp. 433- 455.
Chrisman, J. J., Chua, J. H., Pearson, A. W., \& Barnett, T. 2012. Family involvement, family influence, and family-centered non-economic goals in small firms. Entrepreneurship Theory and Practice. 36(2). 19-39.

Classen, N., Carree, M., Gils, A., \& Peters, B. 2014. Innovation in family and nonfamily SMEs: an exploratory analysis. Small Business Economics. 42(3). 595609.

Creswell, j. W., 2010. Qualitative Inquiry and Research Design: Chosing Among Five Approach. University of Nebraska, Lincoln: SAGE Publication Ltd.

De Massis, A., Federico, F., Pizzurno, E. and Cassia, L., 2011. product innovation in family vs, non-family firms: an eploratory analysis. Small Business Management.

Floren, R. H., 2002. Crown Princess in the Clay: An empirical study of the tackling of sucession challenges in Dutch family farms. AA Aseen: Kloninklijke Van Gorcum.

Higginson, N., 2009. Preparing the next generation for the family business: relational factors and knowledge transfer in mother - to daughter sucession. Journal of Management and Marketing research, pp. 1 - 18.

Jassimuddin, Sajad M.; Klein, Jonathan H.; Connel Con;, 2005. The Paradox of using tacit and explicit knowledge: Strategies to face dilemmas. Management Decision, Vol.43, pp. 102 - 112.

Kimhi, A., 1995. Diferential human capital investments and the choice of sucessor in family firms. American Journal of Agricultural Economics, Volume 76(2), pp. 228-236.

Kimhi, A., 1997. Intergenerational succession in small family businesses: borrowing constraints and optimal timing of succession. Small Business Economics 9, pp. 309 - 318.

Koentjaraningrat, 1984. Kebudayaan Jawa. Jakarta. PN Balai Pustaka. 
Langley, A., 1999. Strategies for theorizing from process data. Academy of Management Review no.4, Volume 24, pp. $691-710$.

Lee, K. S., Lim, G. H. and Lim, W. S., 2003. Family business sucession: appropriation risk and choice of sucessor. Academy of Management Review, Vol. 28, No.4, pp. 657 - 667.

Seng, A. W., 2007. Rahasia Bisnis Orang Cina. Bandung. Mizan.

Szulanski, G., 1996. Exploring internal stickiness: Impediment to the transfer of best practices within the firm. Strategic Management Journal 17, pp. $27-43$.

Tatoglu, E., Kula, V. and Glaister, K. W., 2008. Sucession planning in family - owned business: Evidence from Turkey. International Small Business Journal, p. 26: 155 .

Trevinyo-Rodriguez, R. N. and Tapies, J., 2006. Effective knowledge transfer in family firms. In: P. Z. Poutziouris, K.
X. Smyrnios and S. B. Kein, eds. Handbook of Research on Family bussiness. Cheltenham, UK: Edwar Elgar Publishing Limited, pp. 343-357.

Unit, T. E. I., 2014. Building Legacies: Family Business Succession in South-East Asia, New York: The Economist Inteligence Unit, Ltd..

Varamaki, E., Pihkala, T. and Routama, V., 2003. The stages of transferring knowledge in small family business succession. Lausanne, Family Business Network 14th Annual World Conference.

Wahyuni, S., 2012. Qualitative Research Method: Theory and Practice. Jakarta: Penerbit Salemba Empat.

Warnar, P., 2012. Family Business and Knowledge Transfer: How to Survive to The Next Generation. s.1.: Delft University of Technology.

Yin, R. K., 2009. Case Study Research. Thousand Oaks, California: Sage Publication, Inc. 